\title{
Front Matter: Volume 6460
}

, "Front Matter: Volume 6460," Proc. SPIE 6460, Commercial and Biomedical Applications of Ultrafast Lasers VII, 646001 (27 March 2007); doi:

10.1117/12.729350

SDIE Event: Lasers and Applications in Science and Engineering, 2007, San Jose, California, United States 


\title{
PROCEEDINGS OF SPIE
}

\section{Commercial and Biomedical Applications of Ultrafast Lasers VII}

\author{
Joseph Neev \\ Stefan Nolte \\ Alexander Heisterkamp \\ Christopher B. Schaffer \\ Editors
}

21-24 January 2007

San Jose, California, USA

Sponsored by

Amplitude Systèmes (France)

Coherent, Inc. (USA)

Femtolasers Produktions GmbH (Austria)

IMRA America, Inc. (USA)

Spectra-Physics Lasers, Inc. (USA)

Time-Bandwidth Products, Inc. (Switzerland)

Cyber Laser, Inc. (Japan)

SPIE-The International Society for Optical Engineering

Published by

SPIE-The International Society for Optical Engineering

Volume 6460

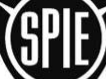

The International Society for Optical Engineering

Proceedings of SPIE-The International Society for Optical Engineering, 9780819465702, v. 6460

SPIE is an international technical society dedicated to advancing engineering and scientific applications of optical, photonic, imaging, electronic, and optoelectronic technologies. 
The papers included in this volume were part of the technical conference cited on the cover and title page. Papers were selected and subject to review by the editors and conference program committee. Some conference presentations may not be available for publication. The papers published in these proceedings reflect the work and thoughts of the authors and are published herein as submitted. The publisher is not responsible for the validity of the information or for any outcomes resulting from reliance thereon.

Please use the following format to cite material from this book:

Author(s), "Title of Paper," in Commercial and Biomedical Applications of Ultrafast Lasers VII, edited by Joseph Neev, Stefan Nolte, Alexander Heisterkamp, Christopher B. Schaffer, Proceedings of SPIE Vol. 6460 (SPIE, Bellingham, WA, 2007) Article CID Number.

ISSN 0277-786X

ISBN 9780819465702

Published by

SPIE-The International Society for Optical Engineering

P.O. Box 10, Bellingham, Washington 98227-0010 USA

Telephone 1 360/676-3290 (Pacific Time) · Fax 1 360/647-1445

http://www.spie.org

Copyright (@ 2007, The Society of Photo-Optical Instrumentation Engineers

Copying of material in this book for internal or personal use, or for the internal or personal use of specific clients, beyond the fair use provisions granted by the U.S. Copyright Law is authorized by SPIE subject to payment of copying fees. The Transactional Reporting Service base fee for this volume is $\$ 18.00$ per article (or portion thereof), which should be paid directly to the Copyright Clearance Center (CCC), 222 Rosewood Drive, Danvers, MA 01923. Payment may also be made electronically through CCC Online at http://www.copyright.com. Other copying for republication, resale, advertising or promotion, or any form of systematic or multiple reproduction of any material in this book is prohibited except with permission in writing from the publisher. The CCC fee code is 0277$786 \times / 07 / \$ 18.00$.

Printed in the United States of America. 


\section{Contents}

vii Conference Committee

ULTRAFAST LASERS IN CELL BIOLOGY AND MICROSCOPY

646004 Attenuation of molecular function by multiphoton excitation-evoked chromophoreassisted laser inactivation (MP-CALI) using green fluorescent protein (Invited Paper) [6460-03]

T. Takamatsu, Kyoto Prefectural Univ. of Medicine (Japan)

\section{ULTRAFAST LASERS IN LIFE SCIENCES}

646007 Laser microtome: all optical preparation of thin tissue samples (Invited Paper) [6460-06] F. G. Will, T. Block, P. Menne, H. Lubatschowski, Rowiak GmbH (Germany)

646008 Development of protein crystallization and processing: femtosecond laser, all solid-state $193 \mathrm{~nm}$ laser, and solution stirring techniques (Invited Paper) [6460-07] Y. Mori, K. Takano, H. Adachi, T. Inove, S. Murakami, H. Matsumura, Osaka Univ. (Japan), SOSHO Inc. (Japan), and CREST JST (Japan); M. Kashii, Osaka Univ. (Japan);

H. Y. Yoshikawa, S. Maki, T. Kitatani, Osaka Univ. (Japan) and CREST JST (Japan); S. Okada, CREST JST (Japan); T. Sasaki, Osaka Univ. (Japan) and SOSHO Inc. (Japan)

\section{APPLICATION OF ULTRAFAST LASERS IN MEDICINE}

64600B Novel oral applications of ultrashort laser pulses (Invited Paper) [6460-10]

V. Wieger, J. Wernisch, E. Wintner, Vienna Univ. of Technology (Austria)

64600C Generation of smooth continuum centered at 1.15 um for ultrahigh resolution OCT [6460-1 1] H. Wang, A. M. Rollins, Case Western Reserve Univ. (USA)

64600D Laser-assisted ablation of corneal-like material using focused femtosecond laser pulses [6460-12]

V. Kohli, D. Yu, A. Y. Elezzabi, Univ. of Alberta (Canada)

Pagination: Proceedings of SPIE follow an e-First publication model, with papers published first online and then in print and on CD-ROM. Papers are published as they are submitted and meet publication criteria. A unique, consistent, permanent citation identifier (CID) number is assigned to each article at the time of the first publication. Utilization of CIDs allows articles to be fully citable as soon they are published online, and connects the same identifier to all online, print, and electronic versions of the publication.

SPIE uses a six-digit CID article numbering system in which:

- The first four digits correspond to the SPIE volume number.

- The last two digits indicate publication order within the volume using a Base 36 numbering system employing both numerals and letters. These two-number sets start with 00, 01, 02, 03, 04, 05, 06, 07, 08, 09, OA, OB ... OZ, followed by 10-1Z, 20-2Z, etc.

The CID number appears on each page of the manuscript. The complete citation is used on the first page, and an abbreviated version on subsequent pages. 
64600E New developments in femtosecond laser corneal refractive surgery [6460-13]

R. Le Harzic, Fraunhofer Institute of Biomedical Technology (Germany) and JenLab GmbH (Germany); C. Wüllner, C. Donitzky, WaveLight AG (Germany); K. König, Fraunhofer Institute of Biomedical Technology (Germany) and Univ. of the Saarland (Germany)

\section{NOVEL ULTRAFAST LASER SOURCES}

$64600 \mathrm{H}$ High-energy high-repetition rate diode-pumped femtosecond amplifier [6460-16] C. Hönninger, A. Courjaud, E. Mottay, Amplitude Systèmes (France); M. Delaigue, I. Manek-Hönninger, Univ. Bordeaux I (France)

64600I MicroJoule level diode-pumped femtosecond oscillator [6460-17]

E. P. Mottay, C. Hönninger, Amplitude Systémes (France)

\section{CHARACTERIZATION AND GENERATION OF FEMTOSECOND LASER PULSES}

64600L High-speed characterization for optical telecommunication signals (Invited Paper) [6460-20]

C. Dorrer, Univ. of Rochester (USA)

64600M Autonomous, flexible, and reliable ultrashort pulse laser at $1552.5 \mathrm{~nm}$ [6460-21]

L. Vaissié, K. Kim, J. F. Brennan, M. M. Mielke, A. Stadler, T. Yilmaz, T. Saunders, D. Goldman, M. J. Cumbo, Raydiance, Inc. (USA)

64600N High-power ultrashort pulses from fiber laser pumped optical parametric amplifier [6460-22]

C. Aguergaray, Univ. of Bordeaux I (France); T. V. Andersen, NKT-Research (Denmark); F. Röser, K. Rademaker, J. Limpert, Friedrich Schiller Univ. (Germany); E. Cormier, Univ. of Bordeaux I (France); A. Tünnermann, Friedrich Schiller Univ. (Germany) and Fraunhofer Institute for Applied Optics and Precision Engineering (Germany)

\section{SPECIAL SESSION: TRENDS IN ATTOSECOND PHYSICS}

64600P Strong-field physics using mid-infrared lasers (Invited Paper) [6460-24]

G. Doumy, C. Blaga, F. Catoire, R. Chirla, P. Colosimo, I. Lachko, A.-M. March, C. Roedig, E. Sistrunk, J. Tate, J. Wheeler, The Ohio State Univ. (USA); H. G. Muller, FOM, AMOLF (Netherlands); P. Agostini, L. F. DiMauro, The Ohio State Univ. (USA)

64600Q Direct temporal characterization of attosecond pulse trains (Invited Paper) [6460-25] T. Shimizu, RIKEN (Japan); T. Okino, K. Yamanouchi, The Univ. of Tokyo (Japan); Y. Nabekawa, K. Midorikawa, RIKEN (Japan)

64600R Momentum shearing interferometry of electron waves (Invited Paper) [6460-26] T. Ruchon, T. Remetter, P. Johnsson, J. Mauritsson, E. Gustafsson, M. Swoboda, A. L'Huillier, Lund Univ. (Sweden) 
OPTICAL WAVEGUIDES I: JOINT SESSION WITH CONFERENCE 6458A

$64600 \mathrm{~V}$ Coupling management of fs laser written waveguides [6460-30]

A. Szameit, F. Dreisow, M. Heinrich, T. Pertsch, S. Nolte, Friedrich-Schiller-Univ. Jena (Germany); A. Tuennermann, Friedrich-Schiller-Univ. Jena (Germany) and Fraunhofer Institute for Applied Optics and Precision Engineering (Germany)

64600W Optical and structural properties of waveguides in $\mathrm{LiNbO}_{3}$ fabricated by ultrashort laser pulses [6460-31]

J. Burghoff, H. Hartung, S. Nolte, Friedrich-Schiller-Univ. Jena (Germany); A. Tünnermann, Friedrich-Schiller-Univ. Jena (Germany) and Fraunhofer Institut für Angewandte Optik und Feinmechanik (Germany)

OPTICAL WAVEGUIDES II: JOINT SESSION WITH 6458A

$64600 Z$ Inscribing fiber Bragg gratings using IR-fs pulses and a phase-mask scanning technique: potential and applications [6460-34]

E. Wikszak, J. Thomas, S. Nolte, Friedrich-Schiller-Univ. Jena (Germany); A. Tünnermann, Friedrich-Schiller-Univ. Jena (Germany) and Fraunhofer Institute for Applied Optics and Precision Engineering (Germany)

FUNDAMENTALS OF LASER MATERIAL INTERACTIONS: JOINT SESSION WITH CONFERENCE 6458A

646010 Modeling of ultrashort pulse propagation and nonlinear plasma formation in transparent Kerr media using realistic initial conditions [6460-35]

C. L. Arnold, Laser Zentrum Hannover e.V. (Germany); W. Ertmer, Univ. Hannover

(Germany); H. Lubatschowski, Laser Zentrum Hannover e.V. (Germany)

NANOSCALE MACHINING AND JOINING: JOINT SESSION WITH CONFERENCE 6458A

$646014 \quad$ Ultrafast pulsed laser ablation for synthesis of nanocrystals [6460-39]

B. Liu, Z. Hu, IMRA America, Inc. (USA); Y. Chen, K. Sun, X. Pan, Univ. of Michigan (USA);

Y. Che, IMRA America, Inc (USA)

646015 An ultrashort pulse laser lathe for axisymmetric micromachining of explosives [6460-40] J. A. Palmer, E. J. Welle, Sandia National Labs. (USA)

646017 Joining of transparent materials by femtosecond laser pulses [6460-42] W. Watanabe, National Institute of Advanced Industrial Science and Technology (Japan): S. Onda, T. Tamaki, K. Itoh, Osaka Univ. (Japan)

\section{POSTER SESSION}

646018 Laser microwelding of silicon and borosilicate glass using nonlinear absorption effect induced by 1558-nm femtosecond fiber laser pulses [6460-43]

T. Tamaki, Osaka Univ. (Japan); W. Watanabe, National Institute of Advanced Industrial Science and Technology (Japan); K. Itoh, Osaka Univ. (Japan) 
64601C Visualization of light propagation in fs written waveguide arrays [6460-47]

F. Dreisow, A. Szameit, T. Pertsch, S. Nolte, Friedrich-Schiller-Univ. Jena (Germany);

A. Tuennermann, Friedrich-Schiller-Univ. Jena (Germany) and Fraunhofer Institute for Applied Optics and Precision Engineering (Germany)

64601D High-sensitivity femtosecond gas phase pump-probe experiments using a hollow waveguide: intramolecular redistribution processes in $\mathrm{CH}_{3} \mathrm{I}$ [6460-48]

V. Krylov, ETH Zurich (Switzerland) and State Univ. of Information Technologies, Mechanics, and Optics (Russia); A. Kushnarenko, E. Miloglyadov, M. Quack, G. Seyfang, ETH Zurich (Switzerland)

Author Index 


\title{
Conference Committee
}

\author{
Symposium Chairs \\ Friedrich G. Bachmann, Rofin-Sinar Laser GmbH (Germany) \\ Henry Helvajian, The Aerospace Corporation (USA) \\ Symposium Cochairs
}

L. N. Durvasala, DARPA (USA)

Jan J. Dubowski, Université de Sherbrooke (Canada)

Program Track Chairs

Henry Helvajian, The Aerospace Corporation (USA)

James S. Horwitz, U.S. Department of Energy (USA)

Conference Chairs

Joseph Neev, JYNI Inc. (USA)

Stefan Nolte, Friedrich-Schiller-Universität Jena (Germany)

Alexander Heisterkamp, Laser Zentrum Hannover e.V. (Germany)

Christopher B. Schaffer, Cornell University (USA)

Program Committee

James E. Carey III, Harvard University (USA)

Donald J. Harter, IMRA America, Inc. (USA)

Daniel J. Kane, Southwest Sciences, Inc. (USA)

Milutin Kovacev, Universität Hannover (Germany)

Eric Mazur, Harvard University (USA)

Nozomi Nishimura, Cornell University (USA)

Minoru Obara, Keio University (Japan)

Andreas Ostendorf, Laser Zentrum Hannover e.V. (Germany)

Brent C. Stuart, Lawrence Livermore National Laboratory (USA)

Alexander Szameit, Friedrich-Schiller-Universität Jena (Germany)

Philbert S. Tsai, University of California, San Diego (USA)

Alfred Vogel, Medizinisches Laserzentrum Lübeck GmbH (Germany) and Universität zu Lübeck (Germany)

\section{Session Chairs}

$1 \quad$ Ultrafast Lasers in Cell Biology and Microscopy

Christopher B. Schaffer, Cornell University (USA)

$2 \quad$ Ultrafast Lasers in Life Sciences

Alexander Heisterkamp, Laser Zentrum Hannover e.V. (Germany) 
3 Application of Ultrafast Lasers in Medicine Joseph Neev, JYNI Inc. (USA)

$4 \quad$ Novel Ultrafast Laser Sources

Lawrence Shah, IMRA America, Inc. (USA)

5 Characterization and Generation of Femtosecond Laser Pulses

Joseph Neev, JYNI Inc. (USA)

6 Special Session: Trends in Attosecond Physics I

Milutin Kovacev, Universität Hannover (Germany)

7 Special Session: Trends in Attosecond Physics II

Katsumi Midorikawa, RIKEN (Japan)

8 Optical Waveguides I: Joint Session with Conference 6458A

Alfred Vogel, Medizinisches Laserzentrum Lübeck GmbH (Germany) and Universität zu Lübeck (Germany)

$9 \quad$ Optical Waveguides II: Joint Session with Conference 6458A

Stefan Nolte, Friedrich-Schiller-Universität Jena (Germany)

10 Fundamentals of Laser Material Interactions: Joint Session with

Conference 6458A

Alexander Szameit, Friedrich-Schiller-Universität Jena (Germany)

11 Nanoscale Machining and Joining: Joint Session with Conference 6458A

Vladimir V. Semak, The Pennsylvania State University (USA)

David Ashkenasi, Laser-und Medizin-Technologie GmbH (Germany) 